\title{
A view on post-Keynesian interest rate policy
}

\author{
Giorgos Argitis*
}

The dominant role of the "new consensus models" in central banks' policymaking in the last two decades has triggered the reaction of post-Keynesian economists to examine alternatives to inflation-targeting monetary strategies and to Taylor-type interest rate rules. This paper develops a simple macroeconomic model in order to pinpoint the distributional/demand effects of rentiers' interest income in a money/debt-using and demand determined economy. The ultimate objective of this model is to provide a starting point for the development of a post-Keynesian approach to interest rate policy that differs from the "activist" and the "parking-it" approaches.

JEL classifications: B22, D33, EI2, E24, E3I, Es2

Keywords: monetary policy, interest rates, income distribution, inflation, unemployment

\section{Introduction}

In the last two decades, the theoretical and practical concern of monetary and interest rate policy-making has encapsulated the main ingredients of the "new consensus models" (NCMs). The NCMs combine a range of features that are the outgrowth of a synthesis of new classical macroeconomics, new Keynesian macroeconomics, monetarism and the real business cycle theory (Goodfriend/King 1997, Allsopp/Vines 2000, Goodfriend 2007, Blanchard 2008, Woodford 2003 and 2009). These models suggest to central banks that

* University of Athens. The paper was presented at the Eastern Economic Association Annual Conference 2009, New York, February 27-March I, 2009. I have benefited from helpful comments made by session participants. I would also like to thank two anonymous referees and Eckhard Hein for their constructive comments and useful suggestions. Responsibility for any remaining errors rests with me alone.

Correspondence Address:

Prof. Giorgos Argitis, National and Kapodistrian University of Athens, Department of Economics, 8 Pesmazoglou Street, Athens, Greece, e-mail: gargeitis@econ.uoa.gr.

Received I4 July 2010, accepted 20 December 2010

C) INTERVENTION 8 (I), 2OII, 9I-II2 
they should put into practice "inflation-targeting "strategies and to use a policy reaction function based on a "Taylor-type interest rate rule« in order to adjust their policy rate towards a »natural « interest rate, so as to respond to output gaps and to deviations of actual inflation from their inflation-target (see e.g. Taylor 1993, Clarida et al. 1999, Romer 2000, Woodford 2003, Carlin/Soskice 2006). This restricted discretionary use of the Taylor-type interest rate rule is hypothesised to be an "optimal « monetary policy operating procedure that primarily ensures price stability and, in turn, output stability in the short-run. In the long run, monetary policy is assumed to be neutral, affecting only the inflation rate. On the other hand, fiscal policy is downgraded and conceptualised as a tool to supplement the inflation-targeting strategy (Arestis/Sawyer 2004, Angeriz/Arestis 2009).

On the contrary, post-Keynesian economists ${ }^{\mathrm{I}}$ argue that "inflation-targeting « monetary strategies and the Taylor-type interest rate rules have contributed to the moulding of an unstable and crisis-prone variant of capitalism. The last decade or so, and in the light of the dominant role of NCMs in macroeconomic theory and especially in monetary policymaking, two kinds of post-Keynesian alternative interest rate rules have been put forward, namely the "activist rules" and the "parking-it rules".

The present paper aims to contribute to the discussion concerning the formulation of a post-Keynesian interest rate policy. Our approach differs from the "activist " and the "parking-it« approaches, in so far as we suggest the use of central bank's policy rate to determine the interest income of the rentier sector, as well as a tax-based incomes antiinflationary mechanism that extends incomes policy to incorporate rentiers' interest income. In this mechanism, a specific value should be set for the lending interest rate, which must be determined by what we call a "conventional productivity improvement «, in order to contain inflation and the destabilising distributional role of rentiers' income. By so doing, we set out a simple macroeconomic model that deserves consideration on the possible distributional/ demand effects of rentiers' interest income in a post-Keynesian economy. In light of this objective, we do not deal with the distributional effects of variations in the mark-up owing to changes in the interest rate, as well as with the effects of new borrowing on the effective demand and output. For these issues see the studies by Hein and Ochsen (2003), Hein (2006, 2007 and 2008), Palley (1994), Dutt (2005 and 2006) and Bhaduri et al. (2006).

The remainder of the paper is as follows: In Section 2 we describe the major assumptions and features of the model and derive the short-run goods market equilibrium as well as the distributional and income effects of variations in the interest rate, taken as given are the debtincome ratio of workers and entrepreneurs, the wage share and the mark up. Section 3 briefly reviews the main arguments and suggestions made by the "activist" and the "parking-it" approaches. A detailed critical appraisal of these approaches is out of the scope of this paper. Then we sketch a post-Keynesian approach to interest rate policy, which i) represents a suggestions. See e.g. Lavoie/Seccareccia (2004), Gnos/Rochon (2006), Lavoie (2006), Arestis (2006), Rochon/Setterfield (2007), Kriesler/Lavoie (2007), Lima/Setterfield (2008), Arestis/Sawyer (2008), Hein et al. (2009), Hein/Stockhammer (2010). 
clear break with inflation-targeting and the Taylor-type interest rate rules; ii) carries out the post-Keynesian political program of full employment and a move towards a more civilised social order; iii) is not exhausted by the fine-tuning of the economy; iv) aims to stimulate entrepreneurship and productive investment in line with Keynes's social theory and political philosophy. Finally, Section 4 summarizes and concludes.

\section{Potential roles of the interest rate in a post-Keynesian economy ${ }^{2}$}

We assume a short-period ${ }^{3}$ closed economy without any state activity, which has the following features:

I) It describes a money/debt-using economy that incorporates three major institutional sectors/social groups: Keynes's (1923, 1925 and 1936) investing class or rentiers, i.e. wealthy individuals, private banks, financial institutions; entrepreneurs, or "active class", which runs industrial activities; and the labour class. Entrepreneurs are supposed to establish, apart from money wage and price contracts, financing (debt and interest rate) contracts with rentiers to overcome the gap between their expenditures for the means of production and the realization of sales revenue. Further, we assume that workers may also need to establish financing contracts with rentiers to finance part of their consumption expenditures.

If such contracts to finance investment and consumption are recognised, then, as Minsky (I982 and 1986) has remarked, aggregate private spending will be crucially influenced by the financial structure of an economy and the cash outflow commitments of debt holders and their ability to repay certain quantities of money at specific future dates. For this reason, the existence of the endogenously-created money contracts by rentiers that influence cash outflow has a significant role in the expenditure and production activities. Furthermore, as Keynes has pointed out, debt and interest rate contracts are likely to generate an actual divergence of interests and conflicts between the rentiers and the "active earning classes" of workers and entrepreneurs (Davidson 2007). Furthermore, we consider the distribution of power in society to be a crucial determinant of the money wage, price and interest rate settings among workers, entrepreneurs and rentiers.

2) Changes in effective demand determine output and employment in the short run and the long run, as is assumed by post-Keynesian macroeconomic theory. There is no

2 Since the 1980 os, there has been an increasing interest in introducing monetary variables, i.e. debt, interest rates and interest payments into post-Keynesian-Kaleckian models of distribution and accumulation, see e.g. Dutt (1989 and 1992), Mott (1989), Jarsulic (1990), Lavoie (1992, I993 and 1995), Dutt/Amadeo (1993), Hein (2006, 2007 and 2008).

3 For simplicity, we assume that there is one type of commodity produced that can be used for both consumption and investment purposes. We also hypothesize that capital stock, technology and labour productivity are exogenously given. 
unique, supply-determined equilibrium level of real output towards which the actual economy automatically gravitates, as it is asserted by NCMs.

3) Inflation is assumed to be primarily cost-determined and the outcome of conflicting claims over the distribution of income (see e.g. Dutt 1992, Palley 1996, Lavoie 2002, Cassetti 2002 and 2003, Lima 2004, Arestis/Sawyer 2005, Hein 2008, Setterfield 2007 and 2009). ${ }^{4}$ Thus, given the productivity relations, a rise in the money income claims of one of the social groups in question is likely to generate inflationary pressures, which, sequentially, are associated with changes in income distribution. In the post-Keynesian literature attention is primarily focused on the wage-price setting and the incomes conflict between wages and profits, or workers and entrepreneurs. In this paper, we place emphasis on rentiers' interest income and the role that the distributional effects of the interest rate is likely to have on the inflation-generating process (see also Hein 2006, 2007 and 2008, Hein/Stockhammer 20I0).

4) Following the post-Keynesian monetary literature, we hypothesise that there is no nonmonetary "natural « interest rate, which equilibrates the money or the loanable funds market (Seccareccia 1998, Arestis/Sawyer 2008). Instead, in our analysis the interest rate is perceived to be a determinant of the distribution of income (Rogers 1989, Lavoie I992 and 1995, Argitis 200I, Hein 2008). Our model considers two specific interest rates: the lending interest rate and the central bank's policy rate. The nominal lending interest rate, $r$, is hypothesised to be set by the rentier sector (actually by the banking sector) as a mark-up, $m>1$, over central bank's policy rate, $i$, that is, $r=m i .^{5}$ Then the rentier sector provides the credit demanded by workers and entrepreneurs who are considered creditworthy at this interest rate. ${ }^{6}$ The central bank's nominal policy rate is administrated in response to a variety of economic, liquidity, social and political pressures. Rentiers' mark-up is assumed to vary according to (a) the dealings between the rentier sector and the entrepreneurs and workers and their relative strength; (b) the risk premium that is associated with rentiers' liquidity preferences (or animal spirits), their confidence and expectations over the future interest rates; c) the underlying regulatory and institutional framework of the banking system.

Let us now define the structure of the model. Equation (1) provides that nominal national income, $Y$, equals the nominal income received by entrepreneurs, $Y_{E}$, and workers, $Y_{w}$, minus the interest payments paid for their stock of debt, which is equal to the nominal income received by the rentier sector, $Y_{R}$ :

4 At this point, we would like to make clear that any attempt at modelling the inflation-generating process in a money/debt-using economy is outside the scope of this paper.

5 This is a standard hypothesis in the post-Keynesian monetary literature. See e.g. Rousseas (1985), Moore (1988), Lavoie (1992), Sawyer (2005), Lima/Meirelles (2003 and 2007), Hein (2008), Hein/ Stockhammer (2010).

6 Needless to say that there is not a unique lending interest rate, but many interest rates as a result of different features of debt contracts. In spite of the fact that our level of abstraction is a significant limitation of our analysis, it is necessary in order to simplify reality and to develop our argument. 


$$
Y=Y_{E}+Y_{W}+Y_{R}
$$

$Y_{E}$ is determined endogenously from macroeconomic conditions and is equal to:

$$
Y_{E}=Y-W-r D_{E} \text {. }
$$

Sales determine $Y$ and prices determine total cash inflows. Workers' wage bill, $W$, equals the money wage rate, $w$, times the level of employment, $L$, where $L=\delta(Y / P)$ and $\delta$ is the ratio of employment to real output; $r D_{E}$ is the interest payments paid to rentiers, which are given by the stock of entrepreneurs' debt, $D_{E}$, and the nominal lending interest rate, $r$. The sum $W+r D_{E}$ equals total cash outflow. If we assume that $\Omega$ is the wage share in nominal aggregate income, then the expected wage bill is $\Omega Y$ and $Y_{E}$ can be written as:

$$
Y_{E}=(1-\Omega) Y-r D_{E} .
$$

Having assumed that workers have accumulated debt, then a part of their wage bill $W$ is used for paying their debt commitments. Therefore, workers' nominal disposable income, $Y_{W}$, equals the wage bill minus the interest payments paid to rentiers, $r D_{w}{ }^{7}$ where $D_{w}$ is workers' stock of debt:

$$
Y_{w}=\Omega Y-r D_{w} .
$$

The income of the rentier sector, $Y_{R}$, is equal to interest payments ${ }^{8}$ received from lending to entrepreneurs and workers, which are determined by the lending interest rate $r$ and the total stock of debt, $D_{E}+D_{W}$, that is given in the short-run:

$$
Y_{R}=r\left(D_{E}+D_{W}\right) \text {. }
$$

Equation (6) gives us the total consumption. Following Kalecki (I97I), we assume that $c_{W}=1$ while $1>c_{E}, c_{R}>0$. A distributional implication of this hypothesis is that whenever income is re-distributed at the expense of workers, consumption decreases. Besides, bearing in mind Keynes's argument that the rentier class constitutes society's richer section with the more inflexible standards of life (Lavoie/Secceraccia 1988), the effects of changes in income distribution in favour of $Y_{R}$ on aggregate consumption are likely to be unfavourable.

$$
C=c_{E} Y_{E}+c_{W} Y_{W}+c_{R} Y_{R}
$$

Equation (6) abstracts from workers' new borrowing possibilities and its macroeconomic implications in order to pinpoint the distributional effects of the interest rate and of the accumulated stock of debt. By means of this simplification, we consider the stock of debt only as a monetary-distribution channel that negatively affects consumption during the debt-burdened period of the cycle, while we do not deal with the effects of new debt contracts on consumption. Other studies have also underlined the important cyclical role that the availability of new credit is likely to have on consumption. For instance, Palley

7 Note that for simplicity we assume that workers and entrepreneurs borrow form banks/rentiers at the same interest rate.

8 In this paper we do not deal with other sources of non-interest rentiers' income, i.e. from holding other liquid financial assets, capital gains and speculation. 
(1994), Dutt (2005 and 2006) and Bhaduri et al. (2006) note that easier access to consumer credit is a factor that has expansionary effect on workers' consumption, and it hence might compensate for changes in the distribution of income at the expense of workers, especially during the business cycle upswing. However, as Palley (1994) and Bhaduri et al. (2006) argue, the expansionary effect of consumer borrowing is likely to be mitigated in the long run by raising the interest payment commitments that reduce households' consumption, generating the contractionary phase of the cycle.

Equation (7) relies on Fazzari et al. (1988, 1998 and 2008)9 ${ }^{9}$ and gives us a simple investment function, which, as in the case of consumption, pays attention only to the importance of cash flow and income distribution on investment decisions: ${ }^{\text {I }}$

$$
I=\alpha_{0}+\alpha_{1}\left[(1-\Omega) Y-r D_{E}\right] .
$$

$\alpha_{0}$ is the exogenous investment, which reflects Keynes's idea of entrepreneurs' animal spirits; the parameter $\alpha_{1}$ reflects, in Minsky's (1982 and I986) and Kalecki's (I937) spirit ${ }^{\text {II }}$, the influence of the internal funds available for investment expenditures. ${ }^{\mathrm{I2}}$ Equation(7) captures several key features of Minsky's investment theory. First, the stock of accumulated debt incurred to finance past investment activities is likely to constrain current investment spending because of contractual debt service and the distributional effect of the lending interest rate. Minsky described this effect "as the way in which the financial trails of past investment affect current investment" (Fazzari et al. 2008: 560). Second, greater internal cash flow raises the amount of investment that entrepreneurs can undertake without incurring the risks and costs associated with external finance. Third, variations in the nominal lending interest rate matter for investment decisions through their distributional impact on internal cash flow.

More specifically, higher nominal lending interest rates increase entrepreneurs' and workers' debt service and are likely to reduce entrepreneurs' internal cash flow and workers' disposable income and, other things being equal, investment and consumption, if $c_{E}>c_{R}$. In addition, income re-distribution between workers and entrepreneurs also affects investment through the impact of the wage share on internal cash flow. However, this allows the possibility that higher interest rates might not affect investment if workers' income falls, leaving internal cash flow unchanged.

Finally, equation (8) implies that the price level, $P$, is determined by the mark-up, $\varphi$, times the index of labor cost, $w \delta$, where $w$ is the money wage rate:

$$
P=\varphi w \delta
$$

9 However, Fazzari et al. (1988, 1998 and 2008) develop dynamic models that also pay attention to the accelerator principle, emphasising the relationship between investment and the change in output. IO For the sake of our argument the investment function abstracts from entrepreneurs' new borrowing and the capacity utilization. The latter is a standard variable in post-Keynesian-Kaleckian investment equations (see e.g. Blecker 2002, Hein 2006 and 2007).

II See Minsky (1982 and 1986), Fazzari/Papadimitriou (1992) and Papadimitriou/Wray (1998).

I2 See the empirical survey by Hubbard (1998) about the relationship between cash flow and investment. 
where

$$
\varphi>1 \text {. }
$$

Inequality (9) implies imperfect competition in the product market. The mark-up is assumed to cover entrepreneurs' income and the interest (plus principal) paid to rentiers for the business sector's stock of debt. Generally, it could be argued that the higher are the firms' interest payment commitments on outstanding debt, the higher is, ceteris paribus, the markup. Interest obligations of firms are likely to be among the factors that affect the mark-up in price-setting, the rate of inflation as well as the functional distribution of income. ${ }^{13}$ Hein (2006 and 2007) distinguishes between two cases to account for the interest effect on prices and distribution: a) an interest inelastic mark-up in which rising debt obligations leave prices and hence workers' income untouched, and hence affect entrepreneurs' cash flow $Y_{E}$ adversely; b) an interest elastic mark-up in which an increase in interest payments is passed to prices, and, ceteris paribus, negatively affects (i) the real burden of debt of entrepreneurs and workers and hence rentiers' income from lending; (ii) the real wages, $w / P=1 / \varphi \delta$, which may encourage workers to demand higher wages triggering conflict inflation. The successful shifting of variations in the interest part of entrepreneurs' cash outflows to prices is supposed to depend on the degree of price competition in the product market and on the relative powers of entrepreneurs and trade unions in the labour market. In our analysis below we only consider the case of an interest-inelastic mark-up.

Furthermore, it is reasonable to argue that higher debt cash payment commitments by workers are likely to positively affect their wage rate demands, the labour cost and hence prices. Our assertion relies on the contributions of Taheri (1995) and Palley (2003), who have argued that there is a positive relation between nominal wage demands and workers' financial obligations. Consequently, it is possible that workers demand a higher wage rate when they face higher interest payments to rentiers for their stock of debt.

Therefore, the relationship between interest rates and inflation is not simple and clear cut. In NCMs when the interest rate increases, aggregate demand and output slows down and inflation decreases, as it is shown by the Phillips Curve. In a post-Keynesian economy, interest payments could be perceived as a channel through which higher rentiers' demands for interest income and hence higher lending interest rates at any level of production, demand and debt are likely to activate inflationary pressures directly, through the interest cost of production, and indirectly, through the stimulation of conflicting claims between workers and entrepreneurs. Thus, the debt payments commitments of workers and entrepreneurs are likely to operate as monetary channels through which changes in the central bank's policy rate and in the mark-up set by the rentier sector affect the rate of inflation. This channel provides the ground for a new look at the incomes claim conflicts process in a capitalist

I3 This assertion relies on the neo-Ricardian and post-Keynesian literature (see e.g. Panico I988, Moore 1989, Pivetti 1991, Argitis 200I, Hein 2006 and 2007) that consider interest payments to be a part of the production cost that may be passed on to prices. This idea has been recently formalized in post-Keynesian/Kaleckian price-setting equations (see e.g. Lima/Meirelles 2003, Hein 2006 and 2007, Lima/Setterfield 20Io). 
economy, and in particular at the role that rentiers' interest income demands may have on inflation, income distribution and the income generating process, as has recently been modeled by Hein and Stockhammer (2010).

We solve the model for the short-run goods market equilibrium assuming given debtincome ratios, wage shares and mark-ups. The equilibrium values for the real incomes of the economy as a whole and of the three groups, $Y / P, Y_{E} / P, Y_{W} / P, Y_{R} / P$, are as follows:

$$
\begin{aligned}
\left(\frac{Y}{P}\right)^{*} & =\frac{a_{0}+r\left[c_{R}\left(D_{E}+D_{W}\right)-\left(c_{E}+a_{1}\right) D_{E}-D_{W}\right]}{\phi w \delta\left[(1-\Omega)\left(1-c_{E}-a_{1}\right)\right]}, \\
\left(\frac{Y_{E}}{P}\right)^{*} & =(1-\Omega)\left(\frac{Y}{P}\right)^{*}-\frac{r D_{E}}{P} \\
& =\frac{a_{0}+r\left[c_{R}\left(D_{E}+D_{W}\right)-\left(c_{E}+a_{1}\right) D_{E}-D_{W}\right]}{\phi w \delta\left[\left(1-c_{E}-a_{1}\right)\right]}-\frac{r D_{E}}{\phi w \delta}, \\
\left(\frac{Y_{W}}{P}\right)^{*} & =\Omega\left(\frac{Y}{P}\right)^{*}-\frac{r D_{W}}{P} \\
& =\Omega \frac{a_{0}+r\left[c_{R}\left(D_{E}+D_{W}\right)-\left(c_{E}+a_{1}\right) D_{E}-D_{W}\right]}{\phi w \delta\left[(1-\Omega)\left(1-c_{E}-a_{1}\right)\right]}-\frac{r D_{W}}{\phi w \delta}, \\
\left(\frac{Y_{R}}{P}\right)^{*} & =r \frac{D_{E}+D_{W}}{\phi w \delta}>0 .
\end{aligned}
$$

If we assume that $1-c_{E}-\alpha_{1}>0$ for stability reasons, the numerator in equation (10) must be positive for the equilibrium output to be positive. Let us now explore the income and distribution effects of variations in $r$. Taking the partial derivatives of $Y / P, Y_{E} / P, Y_{W} / P$ and $Y_{R} / \mathrm{P}$ with respect to $r$, we get the expressions which follow:

$$
\begin{aligned}
& \frac{\partial(Y / P)^{*}}{\partial r}=\frac{\left[\left(c_{R}-c_{E}-a_{1}\right) D_{E}+\left(c_{R}-1\right) D_{W}\right]}{\phi w \delta\left[(1-\Omega)\left(1-c_{E}-a_{1}\right)\right]}, \\
& \frac{\partial\left(Y_{E} / P\right)^{*}}{\partial r}=\frac{\left[\left(c_{R}-c_{E}-a_{1}\right) D_{E}+\left(c_{R}-1\right) D_{W}\right]}{\phi w \delta\left(1-c_{E}-a_{1}\right)}-\frac{D_{E}}{\phi w \delta}, \\
& \frac{\partial\left(Y_{W} / P\right)^{*}}{\partial r}=\Omega \frac{\left[\left(c_{R}-c_{E}-a_{1}\right) D_{E}+\left(c_{R}-1\right) D_{W}\right]}{\phi w \delta\left[(1-\Omega)\left(1-c_{E}-a_{1}\right)\right]}-\frac{D_{W}}{\phi w \delta}, \\
& \frac{\partial\left(Y_{R} / P\right)^{*}}{\partial r}=\frac{D_{E}+D_{W}}{\phi w \delta}>0 .
\end{aligned}
$$


Equations (14), (15) and (16) reveal that the impact of $r$ on $Y / P, Y_{E} / P$, and $Y_{W} / P$ depends (i) on the accumulated debt of workers and entrepreneurs; (ii) on income distribution and in particular on the wage share; (iii) on the propensities to consume of entrepreneurs and rentiers; and (iv) on the responsiveness of investment decisions to changes in cash flow. Accordingly, the relationship between $Y / P, Y_{E} / P$, and $Y_{W} / P$ and the interest rate is institutionally and behaviourally determined and varies among countries that have different institutions and financial structures. Ceteris paribus, if $c_{E}+\alpha_{1}>c_{R}$ an increase in the interest rate might negatively affect $Y / P, Y_{E} / P$, and $Y_{W} / P$, and vice versa. ${ }^{14}$ On the other hand, expression (17) is always positive. A higher nominal interest rate, ceteris paribus, increases interest income.

\section{A post-Keynesian interest rate policy}

Rochon and Setterfield (2007) argue that there are two different post-Keynesian approaches to interest rate policy-making, the "activist rule» and the "parking-it rule«, which form what Rochon (2007) calls the post-Keynesian reaction to the rise of "new consensus macroeconomics " and to the central banks' interest rate policy based on versions of the Taylor rule.

These two approaches share certain features: a) the exogenous and administrative nature of interest rate policy applied by central banks independently from market forces, as well as an endogenous process of money supply; b) the non-existence of a "natural « interest rate, or a Wicksellian rate, that is guaranteeing full employment; c) a cost-determined view of inflation that pays attention to conflicting claims over income and wealth; d) the focus on stabilization by fiscal policy; and e) the focus of macroeconomic policy on employment and growth. Despite the abovementioned similarities, the two approaches emphasise different interest rate operating procedures, although they agree upon the necessity of a cheap money policy.

More specifically, the »activist rule « approach rests on the use of the short-term nominal (or real) interest rate to fine-tune the economy. Moreover, emphasis is on the capacity of central banks to exercise power over the short-term interest rate and to change it in accordance with their overriding economic objectives, preferably growth and employment. Rochon and Setterfield (2007) observe that this approach shares much with the »new consensus « approach to central banking, because it pays attention to the importance of setting the short-term interest rate according to the central bank's reaction function, in which the weight of inflation should be relatively low. Moore (1989 and 1994) describes a reaction function that incorporates short-term interest rates as a dependent variable of a number of exogenous factors, such as estimations about the state of aggregate demand, the economy's responsiveness to interest rate changes, the liquidity of the financial system, and the political-electoral behaviour of

I4 Lavoie (1995) and Hein (2006 and 2007) distinguish between the "normal « and the "puzzling" case to describe the negative and positive effect of the interest rate on economic activity. In our analysis, we pay attention only to the "normal« case, as it is a more probable scenario. 
a country. The thrust of Moore's argument is that central banks should set the interest rate pro-cyclically in order to keep the economy in line with a range of macroeconomic goals, e.g. full employment, price stability, growth, income distribution, etc.

Palley (2006 and 2007) argues that if the economy is wage-led then there is a backwardbending Phillips curve that generates a minimum unemployment rate of inflation (MURI). Palley proposes that central banks should set the interest rate to generate a level of nominal demand growth consistent with hitting the MURI. If the economy is profit-led, then optimal monetary policy will involve a trade-off between lower unemployment and higher wages versus lower growth. Palley notes that an appropriate interest rate policy depends on the settings of fiscal policy and recommends institutional reforms such as financial intermediary balance sheet regulations predicated on asset-based reserve requirements for the stability of the financial system.

Fontana and Palacio-Vera (2006: 55) develop an "asymmetrical opportunistic « approach asserting that "the short-run output-inflation trade off has a (relatively wide) flat section or range of output values for which inflation is roughly constant «. They claim that as long as current output does not exceed the upper bound of the flat section of the short-run outputinflation trade off, lower interest rates may increase current and potential output without pushing inflation up. Consequently, they propose the manipulation of short-term interest rates to encourage the growth rate of output and employment in the short run and achieve price stability in the long run.

As it has already been mentioned, it is not our purpose in this paper to critically consider the two post-Keynesian approaches. However, it is worthwhile to make some remarks on the "activist approach". Gnos and Rochon (2007) question the choice of post-Keynesians to propose a reaction function as an appropriate strategy for central banks to set their policy rate. The thrust of their argument is that there are many factors, such as exchange rates, unemployment, growth, and productivity that may influence or, even more, constrain the decisions taken by central banks when they set interest rates. Gnos and Rochon (2007) further argue that a post-Keynesian view on central banking must recognise that interest rate policy should be carefully weighted against many objectives, such as output, unemployment, capacity utilization and income distribution. They note that the use of a reaction function endogenises interest rate policy. Gnos and Rochon (2007) conclude that in this context, the stabilising capacity of a reaction function framing for monetary policy shall be deemphasised, so that to eliminate what Rochon and Setterfield (2007) have called a "monetary policy dominance in policy-making. Wray (2007) also questions the use of discretionary monetary policy for three major reasons: first, the existence of a simple relationship between inflation and interest rates; second, an active use of interest rates is likely to disrupt financial markets; and third, an active monetary policy conflicts with the "euthanasia" of the rentier sector.

Asensio and Hayes (2009) dispute the feasibility of the "activist rule « approach on the grounds of the uncertainty that characterizes the conventional character of the long-term interest rates. They argue that these rules depend on the assumption that the adjustment of the long-term interest rate is possible to reach as an ideal target; whereby monetary policy has the potential to achieve its major objectives. Asensio and Hayes (2009) pinpoint the 
shifting nature of the state of confidence, which, due to changes in the liquidity preferences of the commercial banks and the participants in the financial markets (see also Lavoie 1999), is likely to reduce the control that central banks might have over the long-term interest rate through their policy rate.

On the other hand, the "parking-it" approach acknowledges the capacity of central banks to administratively set the short-term interest rates, but it does not include a reaction function type of analysis of central banking. Instead, it prefers to specify a rule that sets a value for the nominal (or real) policy rate that should be invariant over the course of the business cycle. Besides, this approach adopts Keynes's concern about the destabilising nature of rentier capitalism and disputes the fine-tuning role of interest rate policy and the importance of the interest rate in regulating aggregate output and employment. However, Rochon and Setterfield (2007) and Wray (2007) argue that what central banks must do is to stop using the interest rate as a short-run fine-tuning policy tool, especially as a tool to fight inflation (see also Davidson 2006).

Rochon and Setterfield (2007) identify three variations of the "parking-it» approach according to their perception and treatment of the »euthanasia of the rentier class. First, the "Smithin rule" (Smithin 2007), which proposes that the "optimal " value of the real interest rate should be zero. Nevertheless, Smithin (2003 and 2004) asserts that if capitalism is to persist as a social order, it must include some sort of bargain with the rentier sector, and argues that a more politically reasonable and practical proposition is the real interest rate target to be a small positive constant that preserves, or slightly enhances, the original purchasing power of accumulated financial capital. Consequently, Smithin proposes that central banks should pursue an interest rate policy of »low but positive« real interest rates.

The second rule is known as the "Kansas City rule" and explicitly suggests that central banks should set the nominal interest rate to zero, making the real rate endogenous to the inflation rate. More specifically, Mosler and Forstater (2004), Wray (2007) and Tymoigne (2009) propose that central banks must set the overnight rate permanently at zero. Wray (2007) calls this policy a "neutral rate" policy, which effectively targets the "euthanasia« of the rentier sector, but is crucially constrained by the exchange rate regime. In particular, Wray suggests that a zero short-term nominal interest rate presupposes a floating exchangerate regime. Wray (2007: 13I) argues in favour of the use of a nominal interest rate target, rather than a real target, for two major reasons: »the nominal rate is the relevant variable for economic decisions and it is a rate the central bank can hit with perfect accuracy«. Tymoigne (2009: II2) argues that setting the overnight rate at zero is not an inflationary policy. On the contrary, fluctuations in interest rates are likely to create price instability through a costpush effect and financial instability through speculative incentives.

The third rule is known as the Pasinetti's "fair interest rate « and proposed by Hein and Stockhammer (2010), Setterfield (2009), Gnos amd Rochon (2007), Rochon and Setterfield (2007), Kriesler and Lavoie (2007), Lavoie (1999) and Lavoie and Seccareccia (1999). The thrust of this rule is that the "fair « rate of interest maintains the purchasing power of funds that are borrowed or lent and hence preserves the intertemporal distribution of income between borrowers and lenders (Lavoie 1999: 4). The rule proposed is that the real interest rate 
should be "equal to the rate of increase in the productivity of the total amount of labour that is required, directly or indirectly, to produce consumption goods and to increase productive capacity" (Lavoie I999: 4). Thus Pasinetti's "fair rate rule« supposes that the rate of interest should not be used to change the distribution of income, but to neutralize the distributional impact of monetary policy. Consequently, Pasinetti's rule does not imply the »euthanasia« of the rentier sector; instead it guarantees rentiers' income share in distribution. Rochon and Setterfield (2007: 26) observe that Pasinetti's rule »sees the rentier class as a necessary evil«. Lavoie (1996: 537) remarks that "the relative situation of the rentiers in the social hierarchy stays the same, whatever economic conditions".

Asensio and Hayes (2009) remark that feasibility, due to uncertainty, is also a question for the "parking-it" rules, which aim to set the real (or nominal) rate of interest at a target or ideal level. These rules are likely to be feasible in favourable circumstances, and especially when we desire to know the ideal policy. Asensio and Hayes (2009) note that in the cases of the "Smithin's rule« and Pasinetti's "fair rate rule» the feasibility problem becomes more complicated because central banks, in order to set the real interest rate, must know the price of liquidity, i.e. the long-term nominal rate which is conventionally determined, and the expected inflation rate. They argue that in an uncertain world, monetary authorities are unlikely to control the long-term real interest rate. Asensio and Hayes (2009) dispute the capacity of central banks to achieve these twin objectives with only one policy instrument, i.e. the overnight real rate, and their constrained capacity to influence the prevailing view about the long-term interest rate.

Furthermore, Asensio and Hayes (2009) argue that the Kansas City rule is not subject to such a limitation, because the short-term nominal interest rate is strongly associated with the central bank's overnight rate. However, they dispute Wray's (2007) call for the "euthanasia" of rentiers by means of the ideal goal of a zero short-term nominal rate. They assert that Keynes, in chapter 24 of the General Theory, suggests the management of the rate of interest in a way that it induces investment, given aggregate consumption, to the level of full employment. In this context, Asensio and Hayes (2009) propose that the interest rate should not be maintained at a low fixed level unconditionally, but adjusted to the levels that ensure full employment, given the marginal efficiency of capital, the aggregate propensity to consume, the volatility of confidence, and conventions. For Asensio and Hayes (2009), a feasible monetary policy must take into account the conventional nature of the long-term interest rate. However, this is a difficult task because monetary authorities are unable to drive the market's view when the future is uncertain.

Arguably, in Keynes's General Theory, a fundamental presupposition for a capitalist economy to achieve full employment is the "euthanasia" of interest, which, under certain conditions, implies the "euthanasia" of the rentier class (see e.g. Argitis 2009). The existence of money and interest, which imply a positive short-term or long-term interest rate, is a fundamental obstacle to full employment, because it holds the marginal efficiency of capital above the full employment level. In the chapters II and I7 of the General Theory, Keynes (I936) conceptualises interest as a monetary phenomenon, which, in the framework of the General Theory, is explicitly associated with the failure of aggregate demand to meet aggregate 
supply. Therefore, these two chapters should be taken into consideration in a more thorough manner. More specifically, in chapter 17, entitled "The Essential Properties of Interest and Money", Keynes generalises the theory of interest to all assets and demonstrates how the own-rate of interest on money "rules the roost", and why it therefore has "predominating practical importance« in analysing the conditions of capital accumulation (see e.g. Dillard 1948, Robinson 196I, Davidson 1978, Rotheim 1981, Chick 1983, Rogers 1989).

Davidson (1978) argues that when the price of money (interest rate) is an alternative preferable to producing new capital assets (investment) or to utilizing existing capital assets, employment of labour will decline. Thus, when it is the highest of all own-rates of interest, the money rate is strategic in impeding new investment, eradicating the likelihood of attaining the full employment of resources. The existence of interest and uncertainty in a laissez-faire policy environment leads to investors in real assets preferring to leave some of the plants idle rather than operate them. This is why Keynes saw rentiers' income as the target of policy interventions in order to increase the propensity to consume, the inducement to invest and economic efficiency. The income received by the rentier sector brings about a cumulative process of contraction in both the consumption and investment expenditures, and hence in output and employment.

Thus, Wray's (2007) suggestion is indeed consistent with Keynes's monetary theory and social philosophy, although it is correctly perceived by Asensio and Hayes (2009) to be an ideal rule. On the other hand, although Pasinetti's "fair rate rule " does neutralize the effect of an interest rate policy on the distribution of income, it guarantees rentiers' income creating barriers to full employment. The same holds, to a lesser extent, for the Smithin's proposal of a low but positive real interest rate rule, which marginally enhances the purchasing power of accumulated financial capital. Thus, the "parking-it" approaches aptly realize the incapacity of monetary policy to stabilize the economy at the full employment level.

\section{An alternative view}

In our view the three "parking-it« approaches are a very welcome addition to the postKeynesian monetary literature. However, the following remarks should be taken into account in post-Keynesian interest rate discussions. First, it is worth making a distinction between rentiers' total income and their interest income. Keynes's social philosophy implies the minimization of rentiers' total income and not only the interest income (Argitis 2009). Wealthy individuals, private banks, financial institutions, etc. hold debt contracts and receive interest income; however they also receive income from holding other non-interest bearing liquid financial assets, fee-based income as well as income from speculative activities in financial markets. This distinction is important especially in modern financial systems that offer a wide range of liquid financial assets. An interest rate policy, ceteris paribus, might therefore change the intra-rentiers income distribution, liquidity preferences and portfolio compositions. 
Second, it is also worth calling to attention that rentiers' interest income is not determined exclusively by the central bank's policy rate, but by the lending interest rate that includes the mark-up set by the rentier sector, as was shown in our model. Expressed differently, even if central banks set the discount rate (nominal or real) equal to zero, the »euthanasia of interest income« might not occur.

Third, it might be reasonable to argue that Keynes's concept of the »euthanasia of rentiers" might put forward his "political aspects of the unfeasibility of full employment of resources in monetary production economies«. Keynes was a brilliant evaluator of the monetary and financial practises, institutions and markets of his time. Moreover, it seems that Keynes had been influenced by Gesell's (1934) critical approach in Natural Economic Order. As a result, Keynes envisioned money (i) as an instrument of power capable of destabilising the market-system and entrepreneurship; and (ii) as a barrier to continuous full employment of resources (Dillard 1942).

Keynes developed a theory to analyse the economic and social consequences of rentier practises in capitalism and a policy program to underpin entrepreneurship and to promote employment in a money-using market economy (Davidson 2007). The "euthanasia of rentiers" seems to be a political concept that can function as a guiding tool to create the institutional architecture, which is necessary for the formation of monetary policy that targets the minimization of rentiers. That has been espoused by Davidson and Davidson (1996) who claimed that such a monetary policy is rather necessary to establish a "civilised society" .

Keynes's pragmatism must drive the design of a post-Keynesian interest rate policy to acknowledge that the non-utilization of resources and the presence of rentiers' nonfunctional income are the inevitable accompaniments of the existence and the function of money contracts, financial markets and financial institutions in capitalist economies. A successful interest rate policy ought to be measured by its contribution to full employment, real growth and a more equitable income distribution and shall be conducted in a way that creates institutions which (i) constrain the speculative activities and the income received by rentiers; (ii) reallocate finance towards entrepreneurship and productive activities; (iii) create positive expectations for entrepreneurs about future returns from holding real assets; (iv) create conditions that prevent a fall in the income of wage-earners; (v) make money and credit markets less vulnerable to animal spirits. Furthermore, and bearing in mind the post-Keynesian/Kaleckian literature, higher lending interest rates and higher rentiers' interest income might be a source of inflationary pressures, through the wage-setting and the price-setting processes, distributional changes and conflicts.

The underlying principle of our view about a post-Keynesian interest rate policy is that it must be designed within a broader institutional setting. Post-Keynesians agree that central bank's interest rate is not the appropriate tool to fight inflation. This hypothesis leads us to think that the inflationary pressures that might arise from higher rentiers' demands for interest income and hence from higher nominal lending interest rates ${ }^{15}$ could be addressed

I5 We emphasise the nominal interest rate as it is the distribution variable for the rentier sector as well as the variable the rentiers/bankers deal with borrowers (see also Tymoigne 2009). 
by instituting a Wallich-Weintraub-Davidson ${ }^{16}$ type tax-based incomes anti-inflationary mechanism that extends incomes policy to incorporate rentiers' interest income. ${ }^{17}$

The idea is that if the nominal lending interest rate is in line with what might be defined as a "conventional productivity improvement", which takes into consideration the prevailing view as to what the value of lender's risk and intermediation costs are expected to be, the inflationary pressures that might arise from higher interest demands and passed to higher wage and price demands could be mitigated without the depressing effects that are likely to be caused by implementing the "new consensus « interest rate-rules. This tax-based incomes policy (TIP) requires the use of an income tax structure to penalise private banks and financial institutions whose lending interest rates increase in excess of the "conventional productivity improvement «. To the extent that a similar income tax structure penalises workers and entrepreneurs from pushing up wages and the mark-up, distributional conflict with positive feedback effects on inflationary pressures can be avoided.

In this framework, private banks and financial institutions are as much responsible as wage bargaining unions and entrepreneurs for stable inflation rates. Once instituted, TIP releases central bank's interest rate policy from what Davidson (2006) calls the monetarist "incomes policy of fear", allowing central banks to focus attention on targeting entrepreneurship, employment and financial stability, without the fear of inflationary expectations. Furthermore, a "conventionally « defined productivity growth rate is a socially constructed variable that could be higher, equal or lower than the labour productivity growth rate included in Pasinetti's "fair rate rule«. Thus, rentiers' interest income shares will adjust to the historically prevailing conventions and ethics about the role of rentiers as well as the distribution of power in society.

Fundamentally, an incomes policy to avoid interest rate-induced inflation involves a redirection of the conventional emphasis. For the "new consensus « economists, to control inflation, effective demand must be depressed via higher interest rates, and the ensuing unemployment dampens, indirectly, wage and price increases. This conservative policy has a specific social target, the workers, and certain distributional effects in favour of the rentier sector, regardless of the possibility that the inflationary pressures might have been stimulated by prior increases in interest rates. This policy disrupts the market forces and generates uncivilised social effects. An incomes policy mechanism projects a direct attack to any source of inflationary money incomes demands and can thus reduce the possibility of a trade-off between inflation and unemployment, which ultimately benefits workers. The success of incomes policy indeed crucially depends on socio-political institutions and processes rather than purely economic circumstances.

I6 See Wallich/Weintraub (I97I), Davidson (I978 and 2007).

I7 Our suggestion extends the related post-Keynesian research, which principally recommends incomes policy as a policy tool to mitigate only upward wage and price pressures. See Hein (2002 and 2004) for reviews of the literature on wage bargaining coordination. See also Hein (2006 and 2008), Kriesler/Lavoie (2007), Setterfield (2007), Lima/Setterfield (2008), Hein/Stockhammer (2010) for the implementation of wage bargaining and the importance of incomes policy in post-Keynesian models. 
Given an incomes tax mechanism to implement an anti-inflationary incomes policy, and in the absence of a Wicksellian "natural « interest rate, an effective post-Keynesian central bank should set its policy rate intending to regulate the profitability of the rentier sector that is the expected profit from lending. More specifically, our post-Keynesian interest rate policy also incorporates the idea of central banks to supply and manage reserves setting the discount rate as low as possible. However, central banks should keep their policy rate there permanently, under the condition that the rentier sector allocates resources towards productive activities. By keeping the discount nominal interest rate permanently low (or at zero), and under the assumption that the lending interest rate equals the »conventional « productivity growth rate, central banks allow the rentier sector to make the maximum profits from lending. In addition, central banks create the confidence that is necessary in forming stable and positive expectations about long-term interest rates as well as about profit from lending in productive investments. So the rentier sector becomes accustomed, sees the future trends of financial markets and all private agents might adjust their liquidity preferences accordingly.

On the other hand, if private banks and financial institutions allocate finance at the expense of productive uses, then central banks must increase their policy rate to squeeze rentiers' interest income. This type of policy discretion in conjunction with an incomes tax policy might induce changes in liquidity preferences and portfolio choices of the banking sector, wealth holders and debt holders that might promote consumption, productive investments, employment and growth without increasing inflation.

Furthermore, this interest rate discretion allows central banks, as controllers of the financial system, to encourage private bankers to increase liquidity as long as the economy has significant idle resources that could be usefully employed. This interest rate policy, arguably, satisfies Keynes's claims that in a world of nonergodic uncertainty, the central bank must have as primary function to provide sufficient liquidity to facilitate economic expansion and growth, and counteract the effects of financial speculation and asset price bubbles, promoting a civilised economic and social order.

However, this framework of post-Keynesian interest rate policy does not imply the »euthanasia of the rentier income«. It rather pinpoints the impossibility for a civilised society to reach the full employment of resources by means of monetary policy in a world where money and financial markets are crucial institutions. This judgment supports the critiques to the "natural « interest rate and to the capacity of the Wicksellian rate to guarantee full employment. Furthermore, this judgment reveals the necessity to exploit the capacity of fiscal policy to target full employment. The absence of discretionary fiscal policy in the NCMs is a significant constraint to macroeconomic stabilization as it has been observed by Arestis and Sawyer (2003 and 2004), Angeriz and Arestis (2009) and Hein and Stockhammer (2010). Substantially at odds with the "new consensus « framework that conceives monetary policy as the perfect substitute for incomes and fiscal policies, our viewpoint conceives fiscal policy as primarily responsible for the management of effective demand at the full employment level and central banks' interest rate policy as supplement to incomes and fiscal policies, so that an economy can operate closer to full employment without the inflationary risk of 
excess demand. Our view is in line with a growing body of post-Keynesian research (Gnos/ Rochon 2007, Smithin 2007, Wray 2007, Rochon/Setterfield 2007, Tymoigne 2009, Hein/ Stockhammer 20IO), which suggests the revitalisation of full policy-mix proposals on the following principles: a countercyclical use of fiscal policy; the use of incomes policy to fight inflation; and an interest rate policy to target rentiers' income.

\section{Conclusions}

In light of the growing concern of post-Keynesians to develop an alternative monetary strategy and interest rate policy to inflation-targeting and to the "Taylor's rule», this paper seeks to contribute to the literature by discussing a post-Keynesian interest rate policy procedure. We have developed a simple macroeconomic model as a starting point in order to show the effects that interest rate policies might have on income distribution, cash flow and output. The normative implications of our model stand in contrast to the implications of the NCMs.

So far, we have argued that the advantage of a post-Keynesian interest rate policy is that its realism should be grounded in the institutional structure of modern monetary economies and derive a richer set of policy options that incorporate incomes policy and fiscal policy. We do not suggest the use of countercyclical interest rate policy. Instead, we argue in favour of "parking « the lending interest rate at a given level determined by a "conventionally« defined productivity growth rate; and central banks should apply discretion in using their policy rate to target the profitability of the banking sector from lending, conditional on funds provided to entrepreneurs to finance investment in real assets. In this way central banks could contribute to macroeconomic policy objectives, such as employment, growth, a more equitable income distribution. However, we argue that macroeconomic stabilization and full employment presuppose the use of fiscal policy and incomes policy to move capitalism towards a more civilised order.

\section{References}

Allsopp, C., Vines, C. (2000): The assessment: Macroeconomic policy, in: Oxford Review of Economic Policy, I6(4), I-32.

Angeriz, A., Arestis, P. (2009): The consensus view on interest rates and fiscal policy: Reality or innocent fraud?, in: Journal of Post Keynesian Economics, 3I(4), 567-586.

Arestis, P. (2006): Is There a New Consensus in Macroeconomics?, New York: Palgrave Macmillan.

Arestis, P., Sawyer, M. (2003): Reinventing fiscal policy, in: Journal of Post Keynesian Economics, 26, 3-25.

Arestis, P., Sawyer, M. (2004): Re-examining Monetary and Fiscal Policies in the Twenty First Century, Cheltenham: Edward Elgar.

Arestis, P., Sawyer, M. (2005): Aggregate demand, conflict and capacity in the inflationary process, in: Cambridge Journal of Economics, 29, 959-974. 
Arestis, P., Sawyer, M. (2008): A critical reconsideration of the foundations of monetary policy in the New Consensus macroeconomic framework, in: Cambridge Journal of Economics, $32(5), 76 \mathrm{I}-779$.

Argitis, G. (200I): Intra-capitalist conflicts, monetary policy and income distribution, in: Review of Political Economy, I4(4), 453-470.

Argitis, G. (2009): Inflation targeting and Keynes's political economy, in: Journal of Post Keynesian Economics, 3I(2), 249-270.

Asensio, A., Hayes, M. (2009): The Post Keynesian alternative to inflation targeting, in: Intervention: European Journal of Economics and Economic Policies, 6(I), 65-79.

Bhaduri, A., Laski, K., Riese, M. (2006): A model of interaction between the virtual and the real economy, in: Metroeconomica, 57, 412-427.

Blanchard, O. J. (2008): The state of macro, Department of Economics, Massachusetts Institute of Technology, Cambridge, Mass., USA, Working Paper Series, No. 08 - I7.

Blecker, R. (2002): Distribution, demand and growth in neo-Kaleckian macro-models, in: Setterfield, M. (ed.), The Economics of Demand-led Growth: Challenging the Supply-Side Vision of the Long Run, Aldershot: Edward Elgar, I29-152.

Carlin, W., Soskice, D. (2006): Macroeconomics, Imperfections, Institutions and Policies, Oxford: Oxford University Press.

Cassetti, M. (2002): Conflict, inflation, distribution and terms of trade in the Kaleckian model, in: Setterfield, M. (ed.), The Economics of Demand-led Growth: Challenging the SupplySide Vision of the Long Run, Aldershot: Edward Elgar, I89-2II.

Cassetti, M. (2003): Bargaining power, effective demand and technical progress: A Kaleckian model of growth, in: Cambridge Journal of Economics, 27, 449-464.

Chick, V.(1983): Macroeconomics After Keynes, London: Philip Allan.

Clarida, R., Gali, J., Gertler, M. (1999): The science of monetary policy: A New Keynesian perspective, in: Journal of Economic Literature, 37(4), I66I-I707.

Davidson, P. (2007): John Maynard Keynes, Hampshire: Palgrave Macmillan.

Davidson, P. (2006): Can, or should, a central bank inflation target?, in: Journal of Post Keynesian Economics, 28(4), 689-703.

Davidson, P. (1978): Money and the Real World, London: Macmillan.

Davidson, G., Davidson, P. (1996): Economics for a Civilised Society, Hampshire: Macmillan.

Dillard, D. (1942): Silvio Gesell's monetary theory of social reform, in: American Economic Review, 32(2), 348-52.

Dillard, D. (1948): The Economics of John Maynard Keynes, Englewood Cliffs: Prentice-Hall.

Dutt, A.K. (1989): Accumulation, distribution and inflation in a Marxian/Post Keynesian models with a rentier class, in: Review of Political Economy, 2I, I8-26.

Dutt, A.K. (1992): Rentiers in Post-Keynesian models, in: Arestis, P., Chick,V. (eds.), Recent Developments in Post-Keynesian Economics, Aldershot: Edward Elgar, 95-I22.

Dutt, A.K. (2005): Conspicuous consumption, consumer debt and growth, in: Setterfield, M. (ed.), Interactions in Analytical Political Economy: Theory, Policy and Applications, Armonk: M.E. Sharpe, $155-178$. 
Dutt, A.K. (2006): Maturity, stagnation and consumer debt: A Steindlian approach, in: Metroeconomica, 57(3), 339-364

Dutt, A.K., Amadeo, E.J. (1993): A post-Keynesian theory of growth, interest and money, in: Baranzini, M., Harcourt, G. (eds.), The Dynamics of the Wealth of Nations, London: Macmillan, I8I-205.

Fazzari, S., Hubbard, G., Petersen, P. (1988): Financing constraints and corporate investment, Brookings Papers on Economic Activity, I, I4I-195.

Fazzari, S., Ferri, P., Greenberg, E. (1998): Aggregate demand and firm behavior: a new perspective on Keynesian microfoundations, in: Journal of Post Keynesian Economics, 20, 527-558.

Fazzari, S., Ferri, P., Greenberg, E. (2008): Cash flow, investment, and Keynes-Minsky cycles, in: Journal of Economic Behavior and Organization, 65, 555-572.

Fazzari, S., Papadimitriou, D. (1992): Financial Conditions and Macroeconomic Performance, New York: M.E. Sharpe.

Fontana, G., Palacio-Vera, A. (2006): Is there an active role for monetary policy in the Endogenous Money Approach?, in: Gnos, C., Rochon, L-P. (eds.), Post-Keynesian Principles of Economic Policy, Cheltenham: Edward Elgar, 49-56.

Gesell, S. (1934): The Natural Economic Order: Money Part, San Antonio: Free Economy Publishing Company.

Gnos, C., Rochon, L-P. (2007): The New Consensus and Post Keynesian interest rate policy, in: Review of Political Economy, I9(3), 369-86.

Gnos, C., Rochon, L-P. (eds.) (2006): Post-Keynesian Principles of Economic Policy, Cheltenham: Edward Elgar.

Goodfriend, M. (2007): How the world achieved consensus on monetary policy, in: Journal of Economic Perspectives, 2I(4), 47-68.

Goodfriend, M., King, R. (1997): The New Neoclassical Synthesis and the role of monetary policy, in: NBER Macroeconomics Annual, I2, 3I-283.

Hein, E. (2002): Monetary policy and wage bargaining in the EMU: Restrictive ECB policies, high unemployment, nominal wage restraint and inflation above the target, in: Banca Nazionale del Lavoro Quarterly Review, 55, 299-337.

Hein, E. (2004): Money, interest and capital accumulation in Karl Marx's economics: A monetary interpretation and some similarities to the Post-Keynesian approach, in: International Papers in Political Economy, II(2), I-43.

Hein, E. (2006): Interest, debt and capital accumulation-a Kaleckian approach, in: International Review of Applied Economics, 20, 337-352.

Hein, E. (2007): Interest rate, debt, distribution and capital accumulation in a post-Kaleckian model, in: Metroeconomica, 57, 310-339.

Hein, E. (2008): Money, Distribution Conflict and Capital Accumulation. Contributions to ,Monetary Analysis‘, Basingstoke: Palgrave Macmillan.

Hein, E., Ochsen, O. (2003): Regimes of interest rates, income shares, savings and investment: A Kaleckian model and empirical estimations for some advanced OECD economies, in: Metroeconomica, 54(4), 404-33. 
Hein, E., Stockhammer, E. (20I0): Macroeconomic policy mix, employment and inflation in a Post-Keynesian alternative to the New Consensus model, in: Review of Political Economy, forthcoming, 22(3), 317-354.

Hein, E., Niechoj, T., Stockhammer, E. (eds.) (2009): Macroeconomic Policies on Shaky Foundations, Marburg: Metropolis.

Hubbard, R.G. (1998): Capital-market imperfections and investment, in: Journal of Economic Literature, 35, 193-225.

Jarsulic, M. (1990): Debt and macro stability, in: Eastern Economic Journal, I5, 9I - IOO.

Kalecki, M. (1937): The principle of increasing risk, in: Economica, 4, 440-47.

Kalecki, M. (197I): Selected Essays on the Dynamics of the Capitalist Economy, Cambridge: Cambridge University Press.

Keynes, J. M. (1923): A Tract On Monetary Reform. (CW: IV), London: Macmillan.

Keynes, J.M. (1925): The Economic Consequences of Mr Churchill. (CW: IX), London: Macmillan.

Keynes, J.M. (1936): The General Theory of Employment, Interest and Money. Cambridge: Macmillan and Cambridge University Press.

Kriesler, P., Lavoie, M. (2007): The new consensus on monetary policy and its Post- Keynesian critique, in: Review of Political Economy, 19(3), 387-404.

Lavoie, M. (1992): Foundations of Post-Keynesians Economic Analysis, Cheltenham: Edward Elgar.

Lavoie, M. (1993): A post-classical view of money, interest, growth and distribution, in: Mongiovi, G., Ruhl, C. (eds.), Macroeconomic Theory: Diversity and Convergence, Cambridge: Cambridge University Press, 3-2I.

Lavoie, M. (1995): Interest rates in Post-Keynesian models of growth and distribution, in: Metroeconomica, 46(2), I46-I77.

Lavoie, M. (1996): Monetary policy in an economy with endogenous credit money, in: Nell, E., Deleplace, G. (eds.), Money in Motion, London: Macmillan, 532-545.

Lavoie, M. (1999): Fair rate of interest and Post Keynesian economics: The Canadian case, Working Paper, URL: http://aixi.uottawa.ca/ - robinson/english/wp/fairratecla.pdf.

Lavoie, M. (2002): The Kaleckian growth model with target return pricing and conflict inflation, in: Setterfield, M. (ed.), The Economics of Demand-led Growth: Challenging the SupplySide Vision of the Long Run, Aldershot: Edward Elgar, I72- I88.

Lavoie, M. (2006): A Post-Keynesian amendment to the New Consensus on monetary policy, in: Metroeconomica, $57(2), 165-192$.

Lavoie, M., Seccareccia, M. (1988): Money, interest and rentiers: The twilight of rentier capitalism in Keynes's General Theory, in: Hamouda, O., Smithin, J. (eds.), Keynes and Public Policy After Fifty Years, Volume 2: Theories and Method, Aldershot: Edward Elgar.

Lavoie, M., Seccareccia, M. (1999): Interest Rate: Fair, in: O’Hara P. (ed.), Encyclopedia of Political Economy, vol. I, London: Routledge.

Lavoie, M., Seccareccia, M. (2004): Central Banking in the Modern World, Cheltenham: EdwardElgar.

Lima, G.T. (2004): Endogenous technological innovation, capital accumulation and distribution dynamics, in: Metroeconomica, 55(4), 386-408. 
Lima, G. T., Meirelles, A. J. (2003): Endogenous banking mark-up, distributional conflict and capacity utilization, in: Metroeconomica, 54(2-3), 366-384.

Lima, G. T., Meirelles, A. J. (2007): Macrodynamics of debt regimes, financial instability and growth, in: Cambridge Journal of Economics, $3 \mathrm{I}(4), 563-580$.

Lima, G.T., Setterfield, M. (2008): Inflation targeting and macroeconomic stability in a Post Keynesian economy, in: Journal of Post Keynesian Economics, 30(3), 435-46I.

Lima, G.T., Setterfield, M. (20I0): Pricing behaviour and the cost-push channel of monetary policy, in: Review of Political Economy, 22(I), 19-40.

Minsky, H. (1982): Inflation, Recession and Economic Policy, New York: Wheatsheaf Books.

Minsky, H. (1986): Stabilizing an Unstable Economy, New York: McGraw Hill.

Moore, B. (1988): Horizontalists and Verticalists: The Macroeconomics of Credit Money, Cambridge: Cambridge University Press.

Moore, B. (1989): On the endogeneity of money once more, in: Journal of Post Keynesian Economics, II(3), 479-487.

Moore, B. (1994): The demise of the Keynesian multiplier: A reply to Cottrell, in Journal of Post Keynesian Economics, I7(I), I2I-I33.

Mosler, W., Forstater, M. (2004): The natural rate of interest is zero, University of Missouri, Kansas City, Working Paper, No. 37.

Mott, T. (1989): The structure of class conflict in a Kaleckian-Keynesian model, Jerome Levy Economics Institute of Bard College, Working Paper, No. 2I.

Palley, T. I. (1994): Debt, aggregate demand and the business cycle: An analysis in the spirit of Kaldor and Keynes, in: Journal of Post Keynesian Economics, 16(3), 371-390.

Palley, T. I. (1996): Post Keynesian Economics: Debt, Distribution and the Macro Economy, New York: St. Martin's Press.

Palley, T. I. (2003): The backward-bending Phillips curve and the minimum unemployment rate of inflation: Wage adjustment with opportunistic firms, in: The Manchester School, 7I $(\mathrm{I}), 35-30$.

Palley, T. I. (2006): A Post-Keynesian framework for monetary policy: Why interest rate operating procedures are not enough, in: Gnos, C., Rochon, L-P. (eds.), Post-Keynesian Principles of Economic Policy, Cheltenham: Edward Elgar, 78-98.

Palley, T. I. (2007): Macroeconomics and monetary policy: Competing theoretical frameworks, in: Journal of Post Keynesian Economics, 30(I), 6I-78.

Panico, C. (1988): Interest and Profit in the Theories of Value and Distribution, London: Macmillan.

Papadimitriou, D., Wray, R. (1998): The economic contributions of Hyman Minsky: Varieties of capitalism and institutional reform, in: Review of Political Economy, Io(2), 199-225.

Pivetti, M. (1991): An Essay on Money and Distribution, Hampshire: Macmillan.

Robinson, J. (1961): Own rates of interest, in: The Economic Journal, 7I(283), 596-600.

Rochon, L-P. (2007): The state of Post Keynesian interest rate policy: Where are we and where are we going?, in: Journal of Post Keynesian Economics, 30(I), 3-II.

Rochon, L-P., Setterfield, M. (2007): Interest rates, income distribution, and monetary policy dominance: Post Keynesians and the "faire rate of interest, in: Journal of Post Keynesian Economics, 30(I), I3-42. 
Rogers, C. (1989): Money, Interest and Capital: A Study in the Foundations of Monetary Theory, Cambridge: Cambridge University Press.

Romer, D. (2000): Keynesian macroeconomics without the LM Curve, in: Journal of Economic Perspectives, I4(2), I49-I69.

Rotheim, R. (198I): Keynes's monetary theory of value (1933), in: Journal of Post Keynesian Economics, 3 (4), 568-85.

Rousseas, S. (1985): A markup theory of bank loan rates, in: Journal of Post Keynesian Economics, $8(\mathrm{I}), \mathrm{I} 35-\mathrm{I} 44$.

Sawyer, M. (2005): Towards a simple macroeconomic model incorporating the key Heterodox propositions, University of Leeds, mimeo, October.

Seccareccia, M. (1998): Wicksellian norm, central bank real interest rate targeting and macroeconomic performance, in: Arestis, P., Sawyer, M (eds.), The Political Economy of Central Banking, Cheltenham: Edward Elgar, I80-198.

Setterfield, M. (2007): The rise, decline and rise of incomes policies in the US during the post-war era: An institutional-analytical explanation of inflation and the functional distribution of income, in: Journal of Institutional Economics, 3(2), 127-146.

Setterfield, M. (2009): Macroeconomics without the LM curve: An alternative view, in: Cambridge Journal of Economics, 33(2), 273-293.

Smithin, J. (2003): Controversies in Monetary Economics: Revised Edition, Cheltenham: Edward Elgar.

Smithin, J. (2004): Interest rate operating procedures and income distribution, in: Lavoie, M., Seccareccia, M. (eds.), Central Banking in the Modern World: Alternative Perspectives, Cheltenham: Edward Elgar, 57-69.

Smithin, J. (2007): A real interest rate rule for monetary policy?, in: Journal of Post Keynesian Economics, 3O(I), IOI-II8.

Taheri, J. (I995): On the persistence of high unemployment in the OECD countries: The real debt resistance hypothesis, in: Journal of Post Keynesian Economics, I7(4), 48I-502.

Taylor, J. (1993): Discretion versus policy rules in practice, in: Carnegie-Rochester Conference Series on Public Policy, December, 195-214.

Tymoigne, E. (2009): Central Banking, Asset Prices and Financial Fragility, Abingdon: Routledge.

Wallich, H., Weintraub, S. (I97I): A tax-based incomes policy, in: Journal of Economic Issues, $5, \mathrm{I}-\mathrm{I} 9$.

Woodford, M. (2003): Interest and Prices: Foundations of a Theory of Monetary Policy, Princeton, NJ: Princeton University Press.

Woodford, M. (2009): Convergence in macroeconomics: Elements of the New Synthesis, in: American Economic Journal: Macroeconomics, I(I), 267-279.

Wray, L.R. (2007): A Post Keynesian view of central bank independence, policy targets, and the rules versus discretion debate, in: Journal of Post Keynesian Economics, 30(I), II9-4I. 